REGULAR ARTICLE

\title{
ALLELOPATHIC EFFECTS FOR THREE PLANTS EXTRACTS ON WEEDS OF WHEAT (TRITICUM AESTIVUM L.)
}

\author{
HUSSEIN ALI SALIM*, ABDALSALAM AWNI ABDALBAKI, HUSSEIN ALI KHALID, HANA SAFI \\ ESHAK, BALKEES RESKI, WISSAM KAHTAN ALWAN
}

Directorate of Diyala Agriculture, Ministry of Agriculture, Iraq

\begin{abstract}
An investigation was carried out to evaluate the allelopathic effects of aqueous extracts of Eucalyptus obligo, Chrysanthemum indicum and Eruca sativa on weeds of wheat in the research field of Kanan region, province of Diyala, Iraq during $2016-2017$. A minimum number of weeds and Dry weight of weeds were significantly recorded $(3.3 \mathrm{~m}-2,15 \mathrm{~g})$ respectively in Eruca sativa extract while maximum control of weeds \% and inhibition of weeds \% (71.2, 87.5\%) were significantly recorded in Eruca sativa extract. Different yield components of wheat, such as crop height and 1000-grain weight showed maximum significantly difference $109.0 \mathrm{~cm}$ and $42.9 \mathrm{~g}$ respectively in Eucalyptus obligo whereas spike length, number of grains/spike, number of plants $/ \mathrm{m}^{2}$ and grain yield revealed maximum significantly difference $11.8 \mathrm{~cm}, 52.6,341$ and $1568 \mathrm{~g}$ respectively in Chrysanthemum indicum.
\end{abstract}

Keywords: Aqueous extract, Eucalyptus obligo, Chrysanthemum indicum and Eruca sativa

\section{INTRODUCTION}

Wheat (Triticum aestivum L.) is one among the cerals which is very important in all countries, as one-third of population depends on it for the caloric requirements [1, 2]. What is cultivated in most of the countries, but the problems from weeds is the major issue which creates heavy yield losses [3]. There are many traditional ways like hand weeding which are useful, but time-consuming. And, the application of chemical weedicides creates negative impact on human and environment [4].

Management of weeds is still a major trouble for the farmers as it is not easy to control them due to their potential risks and costs. Preventive methods are not so practical always [5]. Allelopathic potential of plants to control weeds in wheat field is always getting much interest [6]. There are chances to explore natural products from plants to control weeds, which in turn healthy way to control the weeds and is an ecofriendly approach as well [7]. In this study, an attempt has been made to elaborate the suppressive effect of allelopathic substances of three plant extracts via. Eucalyptus obligo, Chrysanthemum indicum and Eruca sativa on weeds of wheat.

\section{MATERIALS AND METHODS}

The study was carried out during 2016-2017in the research field of Kanan region, province of Diyala, Iraq. The experiment was laid out in RCB design with 3 replications. Wheat variety Iba 99 was used as a test crop. A net plot size was kept $10 \times 10 \mathrm{~m}^{2}$. The seeds were sowed on 1oth December 2016. Dap (diammonium phosphate) and Urea were applied in different plant stages at the rate of $30 a n d$ $65 \mathrm{~kg} /$ acre, respectively. Three plant extracts namely Eucalyptus obligo, Chrysanthemum indicum and Eruca sativa (fig. 1) were sprayed as post-emergence application after 2nd irrigation $54 \mathrm{~d}$ after sowing of seeds in rate 30 $\mathrm{kg} \backslash$ acre whereas treatment of control was sprayed with water only.

Data on different weed species and wheat growth parameters were recorded near crop maturity at 150 DAS (Days after sowing) by using the quadrate measuring $1 \mathrm{~m} \mathrm{x}$ $1 \mathrm{~m}$. Weeds were identified and counted (Table1) whereas dry weight of weeds (gm) was taken after $12 \mathrm{~d}$ of drying under the sun. For the determination wheat growth parameters, 10 plants were randomly selected in each plot. Data were recorded on plant height $(\mathrm{cm})$, spike length (cm), number of grains per spike, 1000-grain weight (g), number of plants $/ \mathrm{m}^{2}$, grain yield (ton ha-1), number of weeds $/ \mathrm{m}^{2}$ and dry weight of weeds $(\mathrm{g})$. Weed control Efficiency \% and dry weeds inhibition \% were calculated according to the following formulas.

The weed control efficiency\% (WCE) was calculated by using formula suggested earlier [8].

\section{Received 14 November 2017; Accepted 31 December 2017 \\ *Corresponding Author}

Hussein Ali Salim

Directorate of Diyala Agriculture, Ministry of Agriculture, Iraq

Email: h_salim11111@yahoo.com

(C) This article is open access and licensed under the terms of the Creative Commons Attribution License (http://creativecommons.org/licenses/by/4.0/) which permits unrestricted, use, distribution and reproduction in any medium, or format for any purpose, even commercially provided the work is properly cited. Attribution - You must give appropriate credit, provide a link to the license, and indicate if changes were made. 
Table 1: Weeds of wheat

\begin{tabular}{llll}
\hline Name of weeds species & Scientific name & Family & Life span \\
\hline Milk thistle & Silybum marianum L. & Compositae & Annual \\
Dwarf mallow & Malva praviflora L. & Malvaceae & Annual \\
Wild oats & Avena fatua L. & Poaceae & Annual \\
lady's lace & Ammi majus & Umbiliferae & Annual \\
wild radish & Raphanus raphanistrum & Poaceae & Annual \\
annual beard-grass & Polypogon monspeliensis & Annual \\
\hline
\end{tabular}

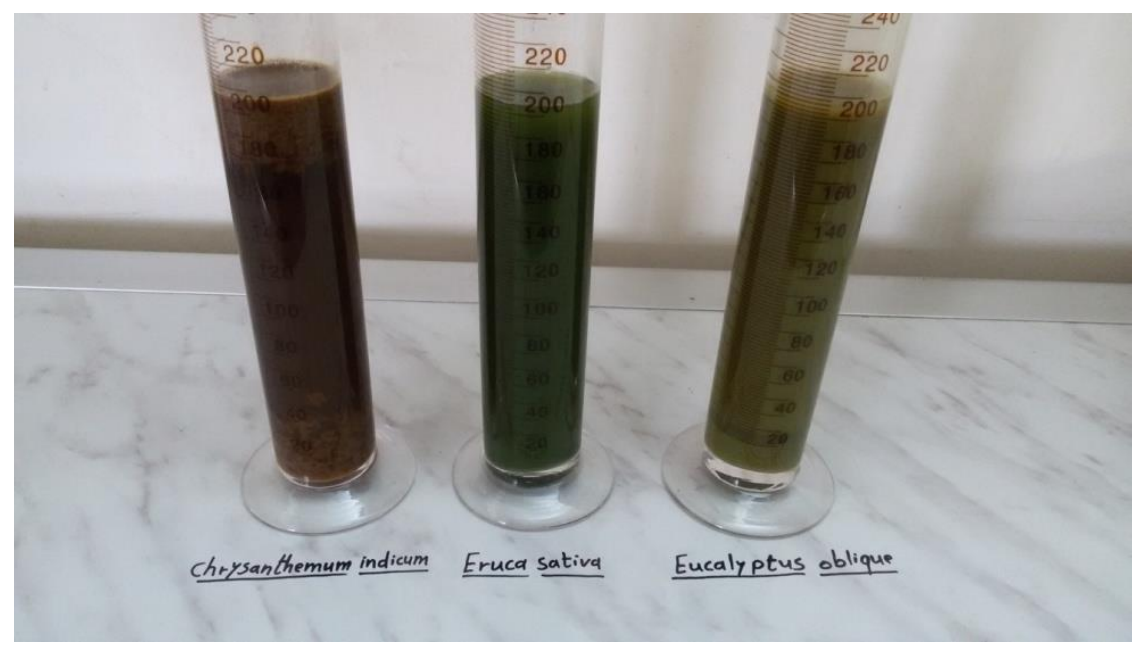

Fig. 1: Aqueous extracts of Chrysanthemum indicum, Eruca sativa and Eucalyptus obligo

\section{RESULTS AND DISCUSSION}

\section{Number and dry weight of weeds}

The application of plant extracts result in significant differences among the treatments in a number of weeds and Dry weight of weeds, a maximum number of the rate $(11.6 \mathrm{~m}-2,120.0 \mathrm{~g})$ respectively were recorded in control (weedy check). A minimum number of weeds and Dry weight of weeds were significantly recorded $(3.3 \mathrm{~m}-2,15 \mathrm{~g})$ respectively in Eruca sativa (table 2).

\section{Weeds control\% and Weeds inhibition\%}

The statistical analysis of the data showed that the maximum control of weeds \% and inhibition of weeds \% $(71.2,87.5 \%)$ respectively were significantly recorded in Eruca sativa extract while the minimum rate was recorded in control (0.0\%) (table 2).

\section{Spike length and crop height (cm)}

The highest spike length and crop height $(\mathrm{cm})$ were recorded $(11.8,109.0 \mathrm{~cm})$ in Chrysanthemum indicum and Eucalyptus obligo respectively with significant differences from other treatments. The minimum rates were recorded in weedy check $(9.6,82.2 \mathrm{~cm}$ ) respectively (table 3$)$.

\section{0-grain weight (g)}

The 1000 grain weight was significantly affected by the plant extracts among the treatments, maximum grain weight of 42.9g was recorded in Eucalyptus obligo followed by Eruca sativa $39.2 \mathrm{~g}$. The minimum 1000 grain weight of $34.0 \mathrm{~g}$ was observed in weedy check (control) (table 3).

\section{Number of grains/spike and number of plants $/ \mathbf{m}^{2}$}

The highest number of grains per spike and number of plants $/ \mathrm{m}^{2}$ were recorded 52.6 and 341respectively in Chrysanthemum indicum extract with significant differences from other treatments. The lowest rates were recorded 36.8 and 313 in weedy check (table 3 ).

\section{Grain yield $\mathrm{g} \backslash$ Acre}

Grain yield was affected by treatments and application of Chrysanthemum indicum increased the grain yield (1568 g acre $^{-1}$ ) as compared to all other treatments. The weedy check recorded significantly lower grain yield (985 $\mathrm{g} \mathrm{acre}^{-1}$ ) (table 3).

Table 2: Main effect of plant extracts on weeds growth parameters

\begin{tabular}{|c|c|c|c|c|}
\hline Treatments & $\begin{array}{l}\text { Number of } \\
\text { weeds } / \mathbf{m}^{2}\end{array}$ & Dry weight of weeds g & $\begin{array}{l}\text { Weeds control } \\
\%\end{array}$ & $\begin{array}{l}\text { Weeds inhibition } \\
\%\end{array}$ \\
\hline control & 11.6 & 120.0 & 0.0 & 0.0 \\
\hline Eucalyptus obligo & $4 \cdot 3$ & 72.5 & 62.5 & 39.5 \\
\hline Chrysanthemum indicum & 9.0 & 72.5 & 23.2 & 39.5 \\
\hline Eruca sativa & 3.3 & 15.0 & 71.2 & 87.5 \\
\hline CD 0.05 & 2.4 & 6.3 & 19.0 & 1.631 \\
\hline
\end{tabular}


Table 3: Components of wheat growth and yield as influenced by various weed control treatments

\begin{tabular}{|c|c|c|c|c|c|c|}
\hline Treatments & $\begin{array}{l}\text { Spike } \\
\text { length cm }\end{array}$ & $\begin{array}{l}\text { Crop } \\
\text { height cm }\end{array}$ & $\begin{array}{l}\text { 1000-grain } \\
\text { weight g }\end{array}$ & $\begin{array}{l}\text { Number of } \\
\text { grains/spike }\end{array}$ & $\begin{array}{l}\text { Number of } \\
\text { plants } / \mathbf{m}^{2}\end{array}$ & $\begin{array}{l}\text { Grain } \\
\text { yield } \\
\text { g \Acre }\end{array}$ \\
\hline Control & 9.6 & 82.2 & 34.0 & 36.8 & 313 & 985 \\
\hline Eucalyptus obligo & 10.5 & 109.0 & 42.9 & 41.0 & 295 & 1298 \\
\hline $\begin{array}{l}\text { Chrysanthemum } \\
\text { indicum }\end{array}$ & 11.8 & 93.7 & 34.9 & 52.6 & 341 & 1568 \\
\hline Eruca sativa & 7.7 & 90.8 & 39.2 & 30.6 & 239 & 1015 \\
\hline CD 0.05 & 0.9 & 4.9 & 0.0 & 11.6 & 1.9 & 2.9 \\
\hline
\end{tabular}

Our results are in agreement with the previous reports [10]. The Eucalyptus showed similar results and its reduced normal weed population by 60 to $95 \%$ [11-13]. Previous studies showed that Eruca sativa seed powder as a bio herbicide which effectively to control weeds $[14,15]$.

\section{CONCLUSION}

From the results, it can be concluded that the weed control can be achieved by the usage of water extract of Eruca sativa, Eucalyptus obligo and Chrysanthemum Indicum in wheat cultivation.

\section{ACKNOWLEDGEMENT}

Authors wish to express their sincere gratitude and appreciation to Directorate of Diyala Agriculture, Ministry of Agriculture, Iraq for awarding the opportunity to accomplish this work.

\section{AUTHORS' CONTRIBUTIONS}

HAS planned and coordinated the research, participated in setting up, analysis and data interpretation, and wrote the article, AAA, HAK, HSE, BR and WKA participated in carried out the field experiment, collected data.

\section{REFERENCES}

1. Khan MA (2003). Wheat crop management for yield maximization. Agriculture Department, Lahore. Pub. Wheat research Institute, Faisalabad., pp. 4-5.

2. Montazeri M, Zand E, Baghestani MA (2005). Weeds and their control in wheat fields of Iran, first ed. Agricultural Research and Education Organization Press, Tehran. Adv. Agron. 58, 57-93.

3. Batish, D. R., K. Arora, H. P. Singh and R. K. Kohli. (2007). Potential utilization of dried powder of Tagetes minuta as a natural herbicide for managing rice weeds, Crop Prot. 26:566-571.

4. Vyvyan, J. R. (2002). Allelochemicals as leads for new herbicides and agrochemicals, Tetrahedron 58:16311636.

5. Labrada, R. (2003). Weed management for developing countries. Addendum 1. Preventive and cultural methods for weed management by Paolo Bàrberi. FAO Plant Production and Protection Paper 120 Add. 1. FAO, Rome, Italy.
6. Singh, H. P., D. R. Batish and R. K. Kohli. (2003). Allelopathic interactions and allelochemicals: new possibilities for sustainable weed management, Crit. Rev. Plant Sci. 22:239-311.

7. Khan, T. D., A. A. Elzaawely, I. M. Chung, J. K. Ahn, S. Tawata and T. D. Xuan. (2007). Role of allelochemical for weed management in rice. Allelopathy J. 19:85-96.

8. Auskalnis, A and Kadzys, A. (2006). Effect of timing and dosage in herbicide application on weed biomass in spring wheat. Agronomy research, 4 (special issue): 133-136.

9. Hameed, K. A., Shati,R. K., Musa A. J.,(2011). Effect chemical control of weeds on yield and component of yield of rice, Kufa Journal of Agricultural Sciences,vol 3,77-84.

10. Qureshi, M. A., A. D. Jarwar, SD Tunio and H. I. Majeedano. (2002). Efficacy of various weed management practices in wheat. Pak. J. Weed Sci. Res. 8(1-2):63-69. [11] Mengal B. S, Sana U. B, Yingying S, Waseem B, L. R Wu, Abdul Raziq S,Hafeez N. B, S. K Baloch, Rameez A. B, Salih A. I. Sabiel, Shabeer A. B, Sultan B,(2015). The Influence of Allelopathic Weeds Extracts on Weeds and Yield of Wheat (Triticum Aestivum L.), Journal of Biology, Agriculture and Healthcare Vol.5, No.1.

11. Bisal, S. S., D. P. S. S Nandal and S. S. Narwal. (1992). Influence of aqueous leaves extracts of Eucalyptus and poplar on the germination and seedling growth of winter crops. Proc. Ind. Soc. Allelop., pp. 95-97.

12. Schumann, A. W., K. M. Little and N. S. Eccles. (1995). Suppression of seed germination and early seedling growth by plantation harvest residues. South African J. Plant and Soil., 12:170-172.

13. Messiha, N. K., S. A. Ahmed, K. G. El-Rokiek, M. G. Dawood and R. R. El-Masry, (2013). The Physiological Influence of Allelochemicals in Two Brassicaceae Plant Seeds on the Growth and Propagative Capacity of Cyperus rotundus and Zea mays L. World Applied Sciences Journal 26: 1142-1149.

14. Ahmed, S. A., K. G. El-Rokiek, R. R. El-Masry and N. K. Messiha, (2014). The Efficiency of Allelochemicals in The Seed Powder of Eruca sativa in Controlling Weeds in Pisum sativum. Middle East Journal of Agriculture Research, 3: 757-762. 